\title{
Impact of Plastics in the
} Floroculture Industry

\author{
Roy A. Larson ${ }^{1}$
}

Additional index words. flowers, containers, substrate, irrigation, recycling

Summary. Plastic products have revolutionized commercial floriculture. Even plastic flowers have caused a new marketing consideration because they are quite competitive with the marketing of live material. Plastic pots are used widely because they are lightweight, attractive, and relatively inexpensive. Plastic flats and trays have been readily accepted by the consumer, and were instrumental in the development of plug culture. Major components of automatic watering systems are made of plastic, and much of the plumbing practiced in commercial floriculture is done with plastic pipe and fittings. Plastic foams are used in floral arrangements, growing media, and propagation cubes or strips. Plastic is used to make steam-sterilization covers, shading material for the manipulation of both light intensity and photoperiod, and mulches or ground covers to help control weeds. Very large quantities of plastic are used in commercial floriculture, and recent landfill restrictions have necessitated procedures for recycling. Recycling procedures are known, but logistics and economics of recycling have not been resolved completely.

I $t$ is difficult to evaluate accurately the impact of a widely accepted new technique or product on an industry because there usually is not a control to enable one to even guess what the current status of the industry would be without it. It is doubtful, however, if the floriculture industry would be as large as it is today if a plastic industry had not been developed. Commercial floriculture became a viable occupation for many people when plastic film greenhouses became an option. These relatively inexpensive structures attracted investment by people who could not afford to build or buy glass-covered structures. Plastic greenhouses have had the greatest impact of plastics on the floriculture industry. 
It is difficult to visualize what floriculture would be like in 1993 if plastic pots and other containers made of plastic, watering systems, media, foams for floral arrangements and propagation were unavailable. Plug culture, a very innovative technique, is much dependent on plastics. The expense of a wooden tray with 200 to 800 cells, either round or square, would have discouraged most growers from adopting such a system. As many as 30 different kinds of plug trays, all made of plastic, can be purchased at reasonable prices.

Plastics have had positive impacts on almost all phases of commercial floriculture, with one major exception. The discovery that flowers could be simulated in plastic did not advance the cause of crop culture, and that impact is discussed first.

\section{Plastic flowers}

The precise year in which plastic flowers were first sold is hard to ascertain, but a 1947 article (Breskin Publ., 1947) described the manufacture of such flowers. William Fan-is (Alhambra, Calif.) used cellulose acetate sheets, plastic rods, vinyl tubing, and methyl methacrylate and made artificial flowers of gardenia, orchid, and calla lily. Wood fiber, paper, cloth, wax, and glass had been used in the manufacture of artificial flowers, but each had major handicaps. Plastic flowers, although appearing to be ii-agile, were resilient and durable. The Japanese were making celluloid flowers in 1955 and vinyl flowers in 1956. Polyethylene flowers were manufactured in Italy in 1957 and, by 1958, Hong Kong had become a major supplier of plastic flowers (Ball, 1961a). Scented plastic flowers soon became available from France and Spain (Cleworth Publ. Co., 1959). Such flowers were made by injection, molding, and extrusion, but most colors were mixed secretively. The manufacture of polyethylene and polyvinyl flowers was part of the economic program "Operation Bootstrap" in Puerto Rico in the late 1950 s in an attempt to improve the local economy.

In 1960, it was estimated that at least $\$ 100$ million worth of plastic flowers were sold in the United States and a $25 \%$ to $35 \%$ annual increase was anticipated (Ball, 1961a). Hong Kong was the largest exporter ofplastic flowers, whereas Italy was considered to be the source of high-quality plastic flowers.

Hong Kong produced $72 \%$ of the plastic flowers in 1961 as low labor costs, such as U.S. \$0.60/day for semi-skilled workers and $\$ 2.50 /$ day for skilled tool makers, made low prices possible. There were 763 firms producing plastic flowers in Hong Kong in 1961, with an employee force of 26,054 people. Wholesalers and retailers expressed little con- tern about the competition between live and plastic flowers, and many retailers considered plastic flowers to be a fad that would last for only about 5 years. The high cost of live flowers and plants in the United States was considered to be the major reason why plastic flowers were more prominent there than in other nations, where inexpensive flowers usually were available. This was apparent in 1961, when more than $\$ 112$ million worth of plastic flowers and plants were sold in the United States, while only $\$ 16$ million worth were sold in the rest of the world (Breskin Publ., 1962).

Recent statistics on the value of plastic flowers are not readily available. As Vic Ball stated in 1961, "Accurate figures are scarce. Plastic flowers are not." (Ball, 1961a).

\section{Plastic labels}

A perusal of catalogs published in the 1950 s would reveal that "plasticards" with information about plant species and culture were available in 1955. The "tag along" labels that became so closely linked with progressive growers and garden centers were advertised in 1958. Advertisements in trade journals in 1958 praised the virtues of purewhite plastic pot labels. The manufacture of plastic pot labels was described by Leaney (1954). Sheets of perspex $<5 \mathrm{~mm}$ thick were cut to make labels 5 inches $(12 \mathrm{~cm})$ long and 1 inch $(2.5 \mathrm{~cm})$ wide. Plastic labels now are available in many lengths. It is easy to write on them, and they do not rot or become discolored. They can become brittle eventually and then break off.

Very attractive plastic labels are used by propagators and growers. Pictures of the flowers or plants and cultural suggestions make the labels very informative to the consumer.

\section{Plastic pots}

Perhaps the most significant impact of plastics in floriculture, with the exception of greenhouse coverings, is their use in the manufacture of pots. Clay was the most widely used raw material in the making of pots until the late 1960s. Jones (1931) observed that people who could not afford to purchase clay pots used nonporous containers such as tin cans and the plants flourished, while those grown in clay pots sometimes grew poorly. Jones and Haskins (1935) studied the distribution of roots growing in media in porous and nonporous containers, and reported that the root systems were almost totally outside the soil mass in porous containers, while root systems in nonporous containers were distributed throughout the media. Ball (1945), while visiting nurseries in Los Angeles, noticed excellent growth of potted plants when
CI to visualize what floriculture would be like in 1993 if plastic pots and other containers made of plastic, watering systems, media, foams for floral arrangements and propagation were

unavailable." 


\section{"Orchids also were popular subjects for early plastic pot evaluations."}

nonporous tin cans were used as containers. Most growers continued to be loyal to clay pots, however, as believed by Ball (1945) when he stated that, "to the end of their earthly chapter most 'old timers' are going to stick to clay pots."

The original designer of plastic pots is hard to trace. William B. Carter of F.I. Carter and Sons (Tewksbury, Mass.) and A.B. Jasquith of the F.W. Woolworth Company were considered to be pioneers in the use ofplastic pots (Patch, 1960). Carter's first order was for 100,000 pots $(3-\mathrm{cm}$ size), manufactured by Union Products, Inc., (Leominster, Mass.). Another pioneering firm, also located in Leominster, was Lockwood Plastics, Inc., a company that had produced clay pots for 195 years. These companies are located in the United States, but companies in other countries also contributed to the development of plastic pots. Germany was a leader in plastics research and development, and undoubtedly played a major role in plastic pot development. Plastic pots were pictured in U.S. trade journals in 1946, and similar advertisements probably appeared in European magazines.

More than 1 million plastic flower pots were sold by the Rogers Plastic Corp. (West Warren, Mass.) to five leading floricultural customers in 1950; the total number sold by this one firm in an 11-month period was $>3,500,000$ pots (Breskin Publ., 1950a). This was achieved even though clay pots at the time cost only half as much as plastic pots. Advantages of plastic pots were that they were light in weight, less fragile, cheaper to ship, did not require foil, and had greater moisture retention. Laurie (Ohio State Univ.) was quoted as saying "Plants in plastic pots will grow better than in clay" (Breskin Publ., 1950a).

Much of the early research on plastic pots was conducted on tomato (Lycopersicon esculentum) plants (Hunter, 1952; Jones and Haskins, 1935). Porosity of clay resulted in unequal root distribution and, consequently, in unequal distribution of water and nutrients. Evaporation of moisture from the pot walls was noted. Plants grown in plastic pots required only half as much water as those grown in clay pots for the first 5 weeks but, by week 8 , plants in plastic received $65 \%$ as much water as those grown in porous clay pots (Hunter, 1952). McCall (1959) reported that geranium (Pelargonium hortorum) plants in plastic pots required only one third as much water as those grown in fired red clay pots. Plants in clay pots wilted $48 \mathrm{~h}$ after irrigation, while those in plastic pots did not wilt until after $72 \mathrm{~h}$.

A new design of plastic pots was introduced in 1956 (Ball, 1956). The pots had a wide base for better stability, with a very small rim. Black 2.5-inch $(6-\mathrm{cm})$ plastic pots cost $\$ 17$ per 1000 , while colored pots cost $\$ 19$ per 1000.

Orchids also were popular subjects for early plastic pot evaluations (Davidson and Bennett, 1961; Jones, 1958; Woebse, 1960, 1962). Jones (1958) had seen orchids growing in 19-liter oil cans in Asia, discarded steel military bomb casings in Hawaii, and tin cans in the Philippines. These nonporous containers were used because they were available and cheaper or free. Plastic containers were equally suitable, although Jones admitted that established cultural recommendations had to be 'altered. It took him only a fourth as much time to irrigate 2000 orchid plants in plastic pots as it did to water the same number of plants in clay pots.

Dunham and Fieldhouse (1959) cornpared growth, flowering, and leaf scorch of 'Croft' Easter lilies (Lilium longiflorum) when plants were grown in plastic or clay pots. Plants grown in plastic pots flowered earlier, required less irrigation, and had higher soil temperatures in comparison to clay pots. However, better root systems developed in the clay pots. Although top growth was satisfactory, many growers of Easter lilies, who were well-acquainted with the vigorous root systems and abundant root hairs produced in clay pots, were dismayed when they first examined root systems of plants growing in plastic pots.

A controversial experiment involving pots made of different materials was conducted by Larson and McIntyre (1968). We grew four potted cultivars of chrysanthemums (Dendranthema grandiflora) in clay, plastic, or Styrofoam pots. Similar and satisfactory growth was achieved regardless of the container material. This report prompted a rebuttal by an official of the National Clay Pot Manufacturers' Assn. (Manes, 1969). He postulated that the reason for our success with plastic pots was because of correct watering practices. He argued that home conditions are very different from those encountered at most university greenhouses.

Soil temperatures and water relations as affected by container porosity were studied by Bunt and Kulwiec (1970, 1971). They considered the soil surface to be more important than the container in re-radiation. Daily water loss in the winter from the substrate in plastic pots was $4.4 \mathrm{~g}$, compared to $7.7 \mathrm{~g}$ in clay pots. In the summer, losses were 20 and 27 g, respectively. Bowman (1972) also studied temperatures of the root media in plastic and clay pots and reported slightly warmer temperatures in plastic pots. The highest temperatures were recorded for polystyrene pots.

The effects of pot color on root growth 
has been investigated, with conflicting reported results. Hasek and Sciaroni (1975) observed poor root systems, with a greenish coloration of the roots closest to the pot wall, when 'Annette Hegg' poinsettia (Euphorbia pulcherrima) plants were grown in white or light-green plastic pots. Chlorotic foliage also was observed. Excellent root systems were noted on plants growing under the same conditions, but in dark-green pots. Light transmission was measured, and white 4-inch $($ lo- $\mathrm{cm})$ pots allowed transmission of 1050 foot-candles. Light-green 6 -inch $(15 \mathrm{~cm})$ pots had light transmission of 68 foot-candles, while dark-green 6 -inch $(15-\mathrm{cm})$ pots allowed only 0.1 foot-candle to penetrate the walls. Maisano (1977) did not detect any substantial differences in growth when poinsettias were grown in thin- or thick-walled white pots. Conover and Poole (1979) compared growth of Aglaonema, Ficus, Peperomia, and Chamaedora in black, white, and clear plastic pots $(0,5$, and $14 \mathrm{klx}$ light transmittance). Root systems of Aglaonema and Chamaedora were affected adversely by the higher light intensities.

Functional but decorative containers are desired by interiorscapers (Manaker, 1987), so color is important. Designers prefer pots that are available in an assortment of colors. Adverse effects on root growth, due to light color, thin walls, and excessive light penetration, can be decreased by inserting one container into another. The increase in cost is small, compared to the consequences associated with poor root systems.

Some florists still prefer clay pots. The heavier weight makes delivery easier, as plants usually remain upright. The heavier weight, however, is a handicap to the grower, as plants seldom are handled singly and a flat full of plants in clay pots can be cumbersome.

Plastic pots certainly have had a major impact in floriculture. Their light weight, durability, freedom from algae, and availability in an assortment of colors and sizes are positive traits. Equipment used to mechanize pot filling and moving operations are facilitated when the containers are made ofplastic. Cost of plastic pots is closely linked to fuel prices, a fact very apparent during the fuel crisis in 1973 and 1974, but costs now are not prohibitive. Environmental concerns about the disposal of used plastic pots have been expressed, and recycling is addressed below.

\section{Other containers}

The use of plastic pots has had so much impact on floriculture that it warrants a separate section. There are many other plastic containers now used in floriculture, and they have eased the production, handling, and sales of floral products.
Wooden flats were used for many purposes. The trend towards the use of other materials began in the late 1950s (Ball, 1959). Molded wood pulp, impregnated with asphalt to improve strength, was used in the manufacture of market paks. These packs were semi-porous. Plastic packs were then introduced, with either thin or thick walls. Peat or plastic pots were placed in the plastic packs (Wright, 1962).

Elwell and Boodley (1967) compared growth of bedding plants in six different types of containers and found the best growth occurred when plants were grown in six-unit, rigid, plastic containers: Colegrave (1973) listed low cost, eye appeal, requirement for less substrate, preference by many retailers, improved transplanting, requirement for less storage space, and light weight as major advantages of using plastic seed trays, packs, and pots. The reported disadvantages were fragility, difficulty of filling with compost, increased time for transplanting, and nonbiodegradability.

Vacuum seeding and plug culture have revolutionized the bedding plant industry in recent years, and now plug production is being used for other crops (Corield, 1989). This innovative practice would have been hard to achieve without plastic. Trays contain 128 to 800 units or cells. The need for sterile plug trays for seed germination requires that new trays should be used for each sowing and that an accumulation of old trays can occur. Recycling companies do exist, and some recycling companies will pay shipping costs if the distance does not exceed 1000 miles.

Shipping of geranium cuttings in a new form of plastic pack reduced losses because root systems were not disturbed in the individual units in the pack, and moisture was not lost through the sidewall (Yoders, 1965). There were other advantages of this new pack, such as reduced crushing and bruising of cuttings during shipment, and improved plant response after planting. Cuttings did not have to be transplanted immediately upon arrival.

Plastic culture vessels are used in tissueculture propagation. Micropropagation has become a standard procedure for propagating several floricultural crops.

Also included among other containers would be those used for holding flowers in the wholesale house and retail outlet. Floral preservatives do not react with plastic as they do with metal, so floral longevity is enhanced. Plastic vases also are widely used by consumers.

Nutritional research was improved when plastic containers became available. Contamination from metal water pipes and from containers hampered many nutrient studies, par-

"Vacuum
seeding and plug
culture have
revolutionized
the bedding plant
industry in
recent years...
This innovative
practice would
bave been bard to
achieve without
plastic."

plastic." 
ticularly on trace elements. Plastic tubing, dispensers, analytical equipment, and containers kept the solutions from being contaminated (Dozer and Dole, 1952).

Plastic is not subject to corrosion, so plastic pesticide sprayers and fertilizer injectors often are used. The light weight of plastic also is an asset during spraying (Sheard, 1956).

\section{Plastic foam}

Plastic has been used to produce foam that can be used in making floral arrangements, propagation blocks, and ingredients for growing media. Foam for holding cut flowers in arrangements replaced chicken wire in the mid $1950 \mathrm{~s}$, when materials such as Oasis Floral Foam (Smithers-Oasis, Kent, Ohio) were introduced. The foam also acted as a reservoir for water. Research showed that roses gained more weight by water absorption when they were placed in water with a good floral preservative than when they were placed in foam, but attributes of foam have made it a popular product (Ball, 1957b; Sager et al., 1964).

Direct rooting in sand in the propagation bench was replaced by the use of peat pots for many crops and now synthetic foams are used widely. Cubes or strips are available in several sizes. These phenolic foams are sterile, so newly stuck cuttings are not as susceptible to plant pathogens causing rot. Foam strips are constructed so that each unit within the strip can be broken off with no injury to the root systems, and cuttings can be transplanted quickly. The ability to retain moisture and the light weight of the foam products make air shipments feasible.

Foams also are used as substrates, usually to improve aeration and drainage (DeBoodt and Verdonck, 1971). The flakes are odorless, chemically neutral, and do not interfere with plant growth (Werminghausen, 1972). The plastic that Bunt (1976) successfully used as a potting medium was composed of $75 \%$ peatmoss and $25 \%$ polystyrene (by volume) for cyclamen (Cyclamen persicum Mill.), fuchsia (Fuchsia hybrida), and gloxinias [ Sinningia speciosa (Lodd. Hiern)], and 50 peat : 50 polystyrene (by volume) for epiphytic plants.

\section{Plastic watering systems}

Vinyl hoses preceded many more-complex watering systems. Vinyl hoses were lighter than rubber hoses, did not crack or rot, and were long-lasting (Breskin Publ., 1950c). The Sandee Manufacturing Co. (Chicago) sold vinyl hoses in the 1940s. The early versions would lose their tensile strength in the sun. They also cost almost twice as much as a rubber hose.

In 1948 , about $12 \%$ of the garden hoses sold in the United States were made of vinyl; a year later the percentage had risen to $20 \%$ to $30 \%$. Improvements had been made, such as better extrusion compounding of materials, and design of hose and fittings.

Plastic pipe was accepted quickly by greenhouse operators as the material was resistant to most chemicals, lightweight, and easy to install (Breskin Publ., 1950b). The butyrate form was used for greenhouse irrigation systems when semi-rigid pipe was wanted (Allred, 1954). High light intensities and temperatures commonly found in greenhouses prompted recommendations that plastic pipe should only be placed underground.

In 1953, a watering system made of plastic was introduced to commercial floriculture. One system was made of 8-mil, opaque polyethylene plastic. The tubes were deflated unless water was running through them. This system had two tubes on the soil surface, running the length of the bench. The perimeter watering system was mounted on the edges of the bench. Both systems were used in cut flower production (Ball, 1957a). A handicap was that the systems had to be removed after each crop, as the fittings could not withstand the temperatures used in soil "sterilization." Drip irrigation systems for cut flowers have been described (Chapin, 1974), in which plastic also is a prominent feature.

Potted floricultural crops can be watered automatically, and plastic tubes and fittings are integral parts of the systems. The Chapin Watermatics system, designed by Chapin Watermatics (Watertown, N.Y.) and the EFlowmatic system, designed by Wolfe (Waco, Texas), were two of the earliest pot watering systems in the United States (Ball, 1961b; Fitzgibbons and White, 1962; White, 1961).

According to Leaversuch (1989), plastic watering systems are cheaper, simpler, and more efficient than systems using metal pipes and fittings. Drip irrigation uses $50 \%$ to $70 \%$ of the water used in other systems. This is a major consideration in an era when greenhouse run-off water is monitored so closely and criticized.

\section{Plastic shade material}

Shade material made from plastic has been available for more than 40 years. The use of Saran shade cloth (Lumite, Norcross, $\mathrm{Ga}$.) accelerated flowering oforchids (Breskin Publ., 1952). The plastic material replaced lath shade, and installation of large pieces was done quickly. Vollebregt (1990) compared $100 \%$ polyester fabric (white) with polypropylene shade and fabric (black). Polypropylene fabric was resistant to dirt adhesion, mechanical abrasion, and algae. It also was low in price. However, polypropylene fabric 
exhibited poor heat retention as well as a lack of light reflection for cooling.

\section{Film plastic for daylength control}

Black film plastic is used by some growers to provide short days for chrysanthemums, poinsettias, kalanchoes (Kalanchoe blossfeldiana Poelln.), and other photoperiodic plants that require short days for flowering when the natural daylength is too long. Several years ago, the mechanisms were devised to enable growers to pull black cloth automatically. Large areas of the greenhouses could be covered simultaneously, with a minimum of labor. The light weight and low cost of black film plastic made this material a viable option. Excessive temperatures under the black plastic, often causing heat delay, could be decreased by the automatic removal of the plastic at night, and replacement before sunrise; long nights were still maintained.

\section{Other uses of plastic in floriculture}

Pasteurization of greenhouse soils was common practice when cut flower production in the United States was flourishing. Plastic sterilizing covers were first used about 1950. Previous covers, made from other material, were heavy and hard to handle. Polyethylene and vinyl plastic covers were light in weight and durable if handled with reasonable care. The material would adhere to bench sides so anchors were not needed to keep the covers in place. Seeley (1953) used the same polyethylene cover 28 times for steam pasteurization at $180 \mathrm{~F}(82 \mathrm{C})$ for $30 \mathrm{~min}$ before it began to crack; he used a vinyl plastic cover 16 times.

Plastic mulches also have been used for floricultural crops. This topic is discussed by Bill Lamont in the next article in this issue of HortTechnology. Kelley (1959) used Bakelite, a black plastic material manufactured by Union Carbide, on asters. The mulch was applied 1 week after planting. No weeding was necessary, and water was conserved.

A very new concept is the use of layers of plastic, separated by a layer of growing medium, in crop culture. The layer of medium is 1.5 to 3 inches ( 4 to $8 \mathrm{~cm}$ ) thick, but can be as little as 1 inch $(2.5 \mathrm{~cm})$. This procedure, referred to as thin-layer culture by GanningerHauck (1992), is cheaper than nutrient film technique, rockwool, or aeroponics. The purpose of thin-layer culture is to eliminate completely any greenhouse run-off water. Government regulations in some European countries allow only $50 \mathrm{ppm}$ nitrogen in the water leaving the premises, and plants use all of the water with this system. Incidentally, water is provided by plastic drip irrigation.

\section{Recycling plastic}

Recently enacted landfill regulations are stringent, and plastic products have been viewed rather critically. Current "burial" fees of $\$ 100 /$ ton $(\% 91 / \mathrm{t})$ have been reported (Leaversuch, 1991). Serious efforts are being made to recycle plastic. Recycling can be done chemically or with very high temperatures. At this time there are not enough facilities to recycle all the used plastic. It is estimated that 100,000 tons $(90,720$ t) of plastic products related to floricultural production, such as pots, trays, and packs, are produced each year in the United States, but only 30 tons $(27 \mathrm{t})$ are recycled (Leaversuch, 1991).

Very few inventions or innovations have had more pronounced effects on the production, shipping and sales of floricultural crops than has the development of plastic. In almost all instances the impact has been positive. The quantity and quality of commercial floriculture in 1993 is much improved over the floriculture that was practiced 50 years ago, and plastic has played a vital role in these improvements.

\section{Literature Cited}

Allred, E. 1954. Plastic pipe for water lines. Minnesota State Florists' Bul. Dec. p. 3-5.

Ball, G.C. 1956. Pots and paks. GrowerTalks 20(8):1-12.

Ball, G.J. 1945. Non-porous pots. GrowerTalks 8(10):30.

Ball, V. 1957a. Plastic tube watering. GrowerTalks $21(7): 14$.

Ball, V. 1957b. Trends in "home flowers". Enter the Aqua-Pak. GrowerTalks 21(4):8-13.

Ball, V. 1959. Modern bedding plant containers. GrowerTalks 22(9):1-6.

Ball, V. 1961a. Facts, figures on the plastic flower boom. GrowerTalks 25(4):1-12.

Ball, V. 1961b. Pot watering automatics. Grower Talks 25(6):1-10.

Bowman, G.E. 1972. The influence of greenhouse covering, propagating bench design and pot type on environmental temperatures. Agr. Meterol. 10:211-223.

Breskin Publications, Inc. 1947. Flowers that retain their beauty. Modern Plastics 24(6):130.

Breskin Publications, Inc. 1950a. Plastic flower pot sales soar. Modern Plastics 27(5):140-141.

Breskin Publications, Inc. 1950b. Plastic pipes invade new markets. Modern Plastics 27(7):69-75.

Breskin Publications, Inc. 1950c. Vinyl hose can take it. Modern Plastics 27(5):142-144.

"Very few
inventions or
innovations have
had more
pronounced
effects on the
production,
shipping and
sales of
floricultural
crops than has the
development of
plastic."

'C Vry few inventions or innovations have had more pronounced effects on the production, shipping and sales of floricultural crops than has the plastic." 
Breskin Publications, Inc. 1952. Greenhouse screen. Modern Plastics 29(8):168.

Breskin Publications, Inc. 1962. The fantastic business of plastic plants and flowers. Modern Plastics 39(8):94-97,205-206.

Bunt, A.C. 1976. Modern potting composts. Allen and Unwin, London. p. 22-26.

Bunt, A.C. and Z.J. Kulwiec. 1970. The effect of container porosity on root environment and plant growth. I. Temperature. Plant \& Soil 32:65-80.

Bunt, A.C. and Z.J. Kulwiec. 1971. The effect of container porosity on root environment and plant growth. II. Water relations. Plant \& Soil 35:1-16.

Chapin, RD. 1974. Drip irrigation for cut flowers. Florists' Rev. 154(3987):61-62, 89-90.

Cleworth Publishing Co., Inc. 1959. Flowers unlimited. Plastics World 17(11):13.

Colegrave, D. 1973. Containers and presentation. Colegrave beddingplants. Grower manual. Grower Books, London. p. 19-35.

Conover, C.A. and R.T. Poole. 1979. Foliage plant response to translucence of the growing container. HortScience 14(5):616-617.

Corfield, J.L. 1989. Containers, p. 66-69. In: H.K. Tayama (ed.). Tips on growing bedding plants. The Ohio State Univ., Columbus. Bul. FP-763.

Davidson, O.W. and D.E. Bennett, Jr. 1961. Clay vs. plastic pots for orchids. Amer. Orchid Soc. Bul. 30:32-38

DeBoodt. M. and O. Verdonck. 1971, Physical properties of peat and peat-moulds improved by perlite and foam plastics in relation to ornamental plant growth. Acta Hort. 18:9-27.

Dozer, I. and M. Dole. 1952. Plastics in trace element research. Science 115:93-94.

Dunham, C.W. and D.J. Fieldhouse. 1959. Growth, flowering and leafscorch of Croft lilies as affected by moisture conditions in clay and plastic pots. Illinois State Florists' Assn. Bul. 199:14.

Elwell, R.N., Jr., and J.W. Boodley. 1967. A comparison of bedding plant containers. N.Y. State Flower Growers' Bul. 256:1-5.

Fitzgibbons, M. and J.W. White. 1962. Soil mixtures, drainage, watering methods and pot mums. Pennsylvania Flower Growers' Bul. 135:2-5.

Ganninger-Hauck, D. 1992. Growing crops out of the ground: Thin layer culture. Floriculture Intl. 2(4):21.

Hasek, R.F. and R.H. Sciaroni. 1975. Light-colored plastic pots affect poinsettia root system. Univ. of Calif. Berkeley, Coop. Ext. Serv. Flower and Nursery Rpt. for Commercial Growers MayJune. p.1.

Hunter, J.A. 1952. Comparison of growth of tomato plants in impervious plastic pots and porous clay pots. New Zealand J. Sci. Tech. Sect. A. $34: 365-368$.

Jones, L.H. 1931. Flower pot composition and its effect on plant growth. Massachusetts Agr. Expt. Sta. Amherst, Bul. 277:147-161.

Jones, L.H. and H.D. Haskins. 1935. Distribution of roots in porous and non-porous plant containers. Plant Physiol. 10:511-519.

Jones, R.W. 1958. Plastic pots. Amer. Orchid Soc. Bul. 27(5):307-308

Kelley, J. 1959. Growing asters by using a black plastic mulch. Florists' Rev. 124(3202):61-62.

Larson, R.A. and M.L. McIntyre. 1968. Pot mum container study. Florists' Rev. 142(3691):18-19, $48-49$

Leaney, E.J. 1954. Plastic pot labels. J. Austral. Intl. Agr. Sci. 20:251-252.

Leaversuch, R.D. 1989. Water, water everywhere: Plastics help make it happen. Modern Plastics 66(8):60-62.

Leaversuch, R.D. 1991. Chemical recycling brings real versatility to solid-waste management. Modern Plastics 68(7):4043.

Maisano, J.J., Jr. 1977. White plastic pots. Connecticut Greenhouse Nws1. 81:20-21.

Manaker, G.H. 1987. Interior plantscapes. Installation, maintenance and management. 2nd ed. Prentice-Hall, Englewood Cliffs, N.J.

Manes, S. 1969. Clay pots defended. Florists' Rev. $143(3711): 12,42,43$.

McCall, W.W. 1959. Moisture studies with greenhouse soils. Michigan Agr. Expt. Sta. Quart. Bul. 42(1):35-42.

Patch, F.W. 1960. Rise of the plastic pot. Florists' Rev. 126(3273):17-18-61,78-79.

Sager, W., C. Schroeder, and P.R. Krone. 1964. Proper use of "foam" materials extends flower life. Minnesota State Florists' Bul. Dec. p. 4-7.

Seeley, J.G. 1953. Plastic sterilizing covers. Pennsylvania Flower Growers' Bul. 28:1,6.

Sheard, G.F. 1956. Polythene in horticulture. Agriculture (London) 63:331-334.

Vollebregt, R. 1990. Analysis ofgreenhouse curtain systems for shading, cooling, and heat retention. Proc. Intl. Plant Prop. Soc. 40:166-175.

Werminghausen, B. 1972. The application of synthetic media in plant propagation. Acta Hort. 26: 159-164.

White, J.W. 1961. Handling young plants, p. 1934. In: J. Mastalerz (ed.). Geraniums. Pennsylvania State Univ., University Park.

Woebse, E.A. 1960. Give some thought to the pot. Amer. Orchid Soc. Bul. 29(4):268-270.

Woebse, E.A. 1962. Plastic pots-two years later. Amer. Orchid Soc. Bul. 31(7):535-536.

Wright, M. 1962. Latest rundown ofcontainers for bedding plants. GrowerTalks 25(10):6-9.

Yodebrothers. 1965. Yoder cultured geraniums 1965-66. Grower Circle News 34:1. 